\title{
Studi Profil Ozon Permukaan (03) Dan Gas Karbon Monoksida (CO) Antara Kota Bandung Dan Bukit Kototabang Tahun 2008
}

\section{Study Of Surface Ozon(O3) And Carbon Monoxide (CO) Profile Between Bandung City And Bukit Kototabang On 2008}

\author{
Andi Sulistiyono (1), Hartanto(1), Fathuroyan(2), Dodi Saputra(1) dan Ikhsan \\ Buyung Arifin(1) \\ (1) Stasiun Global Atmosfere Watch (GAW) Bukit Kototabang \\ (2) Puslitbang BMKG
}

\begin{abstract}
ABSTRAK
OzonPermukaan $\left(\mathrm{O}_{3}\right)$ terbentuk karena adanya proses fotokimia oleh perkusor pembentuknya salah satunya yaitu gas karbonmonoksida (CO). Data parameter gas $\mathrm{CO}$ dan $\mathrm{O}_{3}$ diurnal hasil pengukuran di Stasiun GAW Bukit Kototabang dan Lapan Bandungdianalisis untuk mengetahui profil diurnal gas $\mathrm{CO}$ dan $\mathrm{O}_{3}$ pada tipe wilayah perkotaan (Bandung) dan non-perkotaan (stasiun GAW Bukit Kototabang).Konsentrasi dan profil gas CO secara diurnal untuk wilayah tipe perkotaan dan non perkotaan ditentukan oleh sumber serta waktu emisi dari gas CO. Untuk wilayah tipeperkotaan, grafik diurnal konsentrasi gas CO terdapat periode waktu dengan konsentrasi tinggi dan konsentrasi rendah. Konsentrasii tinggi gas CO terjadi saat warga kota beraktifitas dengan menghasilkan emisi gas $\mathrm{CO}$ pada saat sinar matahari belum panas, sedangkan konsentrasi rendah gas CO terjadi pada periode pembentukan 03 melalui proses fotokimia. Untuk wilayah non perkotaan (Stasiun GAW Bukit Kototabang) tidak terjadi perbedaan secara jelas peningkatan konsentasi CO secara diurnal. Hal ini karena kedudukan stasiun GAW Bukit Kototabang jauh dari perkotaan yang merupakan sumber emisi gas CO. Status kualitas udara ditinjau dari konsentrasi gas $\mathrm{CO}$ dan $\mathrm{O}_{3}$ tahun 2008 untuk wilayah Kota Bandung dan Stasiun GAW Bukit Kototabang masih baik karena berada jauh dibawah nilai baku mutu udara ambien menurut PP No.41 tahun 1999.
\end{abstract}

Kata kunci: Bandung, Bukit Kototabang, Karbon Monoksida, Ozon Permukaan, fotokimia

\begin{abstract}
Surface Ozon $\left(\mathrm{O}_{3}\right)$ is formed due to the photochemical process by its forming constituent, one of which is carbon monoxide (CO). Using diurnal data of $\mathrm{CO}$ and $\mathrm{O}_{3}$ gas parametersfrom the measurements at GAW Kototabang Station and Lapan, Bandung. it was analyzed to find out the diurnal profile of $\mathrm{CO}$ and $\mathrm{O}_{3}$ gases in the types of urban area (Bandung) and Non Urban area (GAW Bukit Kototabang station).The diurnal CO gas concentration and profile for Urban and Non-Urban type regions is determined by the source and the emission time from CO. For Urban type areas, diurnal graphs of CO gas concentration occur peaks and valleys. The peak of $\mathrm{CO}$ concentration occurs when city residents engage in effects on CO gas emissions, while the valley of CO gas concentration is the period of $\mathrm{O}_{3}$ formation through a photochemical process. The Non Urban areas (GAW Bukit Kototabang Station) there is no large difference in concentration values for a certain period considering the position of GAW Bukit Kototabang station is far from the source of gas emissions. Air quality status in 2008 for Bandung city and Bukit Kototabang GAW Station is still in healthy criteria because the value of $\mathrm{CO}$ and $\mathrm{O}_{3}$ gases is below the value of ambient air quality standards according to PP No.41 of 1999.
\end{abstract}

Keywords: Bandung, Bukit Kototabang, Carbon Monoxide, Surface Ozone, Photochemical

Citation: Sulistiyono, A., Hartanto, Fathuroyan, Saputra, D., dan Arifini, I. B. (2019). Study Of Surface Ozon(03) And Carbon Monoxide (CO) Profile Between Bandung City And Bukit Kototabang On 2008. Jurnal Ilmu Lingkungan, 17(2), 239-244, doi:10.14710/jil.17.2.239-244

\section{PENDAHULUAN}

Ozon Permukaan $\left(\mathrm{O}_{3}\right)$ merupakan salah satu polutan sekunder yang terbentuk dari hasil reaksi fotokimia. Ozon ini merupakan polutan udara yang berdampak negatif bagi lingkungan, alam maupun manusia. Fotokimia merupakan reaksi-reaksi kimia yang diinduksi oleh sinar secara langsung maupun tidak langsung. Reaksi fotokimia menerima energi pengaktifan dari penyerapan foton cahaya oleh molekul-molekulnya (Rahmi Susmiati, 2013).

OzonPermukaan $\left(\mathrm{O}_{3}\right)$ disebut sebagai polutan sekunder karena ozon permukaan terbentuk dari rombakan ataupun rubahan partikel-partikel gas yang lain. Sekitar 70\% oksidan kimia di atmosfer bereaksi dengan CO (S. Henne at al, 2007). Karbon monoksida terbentuk dari bahan bakar fosil berbasis karbon, seperti batu bara, minyak, gas alam dan kayu 
bakar serta proses industri yang melibatkan pembakaran bahan bakar fosil.

Karbon monoksida (CO) merupakan salah satu prekursor (pembentuk) ozon yang sangat berpengaruh terhadap proses pembentukan ozon di atmosfer (Spivakovsky et al., 2000). Gas Karbonmonoksida (CO) dan Ozon Permukaan $\left(\mathrm{O}_{3}\right)$ merupakan dua spesi kunci di dalam sistem fotokimia di troposfer bawah (permukaan). Dalam reaksi pembentukan ozon yang melibatkan $\mathrm{CO}, \mathrm{CO}$ bereaksi dengan radikal $\mathrm{OH}$ membentuk atom $\mathrm{H}$ radikal dan $\mathrm{CO}_{2}$ :

$\mathrm{CO}+\mathrm{OH} \rightarrow \mathrm{H}+\mathrm{CO}_{2}$

Atom $\mathrm{H}$ radikal kemudian bereaksi dengan $\mathrm{O} 2$ membentuk hidroperoksi radikal $\left(\mathrm{HO}_{2}\right)$. Radikal $\mathrm{OH}$ juga mengikat hidrokarbon (RH) dan senyawa VOC yang lain untuk membentuk alkyl peroksi radikal $\left(\mathrm{RO}_{2}\right)$.

$\mathrm{HO}_{2}$ dan $\mathrm{RO}_{2}$ mengoksidasi $\mathrm{NO}$ untuk membentuk $\mathrm{NO} 2$.

$\mathrm{HO}_{2}+\mathrm{NO} \rightarrow \mathrm{OH}+\mathrm{NO}_{2}$

$\mathrm{RO}_{2}+\mathrm{NO} \rightarrow \mathrm{RO}+\mathrm{NO}_{2}$

Pembentukan kembali $\mathrm{NO}_{2}$ mengakibatkan ozon terbentuk lebih banyak dalam waktu kurang lebih 1 hingga 2 menit :

$$
\begin{aligned}
& \mathrm{NO}_{2}+\mathrm{hv} \rightarrow \mathrm{NO}+\mathrm{O} \\
& \mathrm{O}_{2}+\mathrm{hv} \rightarrow \mathrm{O}+\mathrm{O} \\
& \mathrm{O}_{3}+\mathrm{O} \rightarrow \mathrm{O}_{2}+\mathrm{O}_{2} \\
& \mathrm{O}_{3}+\mathrm{hv} \rightarrow \mathrm{O}_{2}+\mathrm{O} \\
& \mathrm{O}+\mathrm{O}_{2}+\mathrm{M} \rightarrow \mathrm{O}_{3}+\mathrm{M} \ldots . . . \\
& \text { Dengan } \mathrm{M}=\mathrm{N} 2 \text { atau } \mathrm{O}_{2} \\
& \mathrm{CO}+2 \mathrm{O}_{2} \rightarrow \mathrm{CO}_{2}+\mathrm{O}_{3} . .
\end{aligned}
$$

Dimana atom oksigen $\left(\mathrm{O}_{2}\right)$ yang diperlukan berasal dari reaksi pemisahan ozon yang lain.

Banyaknya Ozon troposfer disuatulokasi tergantung pada proses fotokimia dan fisika, termasuk produksi dan destruksi ozon, transportasi dari sumber-sumber dan sirkulasiangin lapisan atas(Monks, 2000; Lelieveld dan
Dentener,2000).Penelitian menunjukkan bahwa pengaruh CO terus menerus meningkat terhadap pembentukan ozon permukaan. National Research Council America tahun 1999 menyimpulkan bahwa sekitar 20\% ozon permukaan secara langsung berasal dari emisi CO. (Lin Zhang. 2006).

Lapan Bandung dan GAW Bukit Kototabangmerupakan institusi pemerintahan yang menyenggarakan pengukuran $\mathrm{O}_{3}$ dan $\mathrm{CO}$. Menurut Novita Ambarsari et al (2010), Kota Bandung termasuk kota besar dengan tingkat polusi yang cukup tinggi. Hal ini ditandai dengan nilai konsentrasi $\mathrm{CO}$ ambien di stasiun pengukur polusi udara LAPAN Bandung rata-rata di atas 1 part per milion volume (ppmv). Untuk kota-kota besar seperti Bandung, tingkat polusi CO dapat mencapai 1-10 ppmv.

Stasiun GAW Bukit Kototabang merupakan referensi udara bersih terletak cukup jauh dari aktifitas masyarakat sehingga kualitas udara di wilayah tersebut terjaga.Konsentrasi CO rata-rata untuk GAW Bukit Kototabang masih lebih rendah dari 1 ppmv. Perbedaan kondisi wilayah (perkotaan dan non-perkotaan) akan membuat perbedaan terhadap profil diurnal dari konsentrasi CO dan pembentukan gas $\mathrm{O}_{3}$.

Tujuan penelitianini adalah mengetahui profil $\mathrm{CO}$ dan pembentukan $\mathrm{O}_{3}$ pada proses fotokimia di wilayah perkotaan dan non perkotaan. Profil konsentrasi diurnal gas $\mathrm{CO}$ dan $\mathrm{O}_{3}$ akan menggambarkan tentang profil parameter kualitas udara pada 2 daerah (Bandung dan GAW Bukit Kototabang) pada tahun 2008. Selain profil konsentrasi gas CO dan 03, akan didapatkan kualitas udara secara diurnal pada dua daerah tersebut. Untuk waktu ke depan nantinya akan bisa digunakan untuk bahan pertimbangan dan memperkirakan efisiensi pembentukan CO sehingga pembentukan polutan Ozon permukaan bisa dikendalikan.

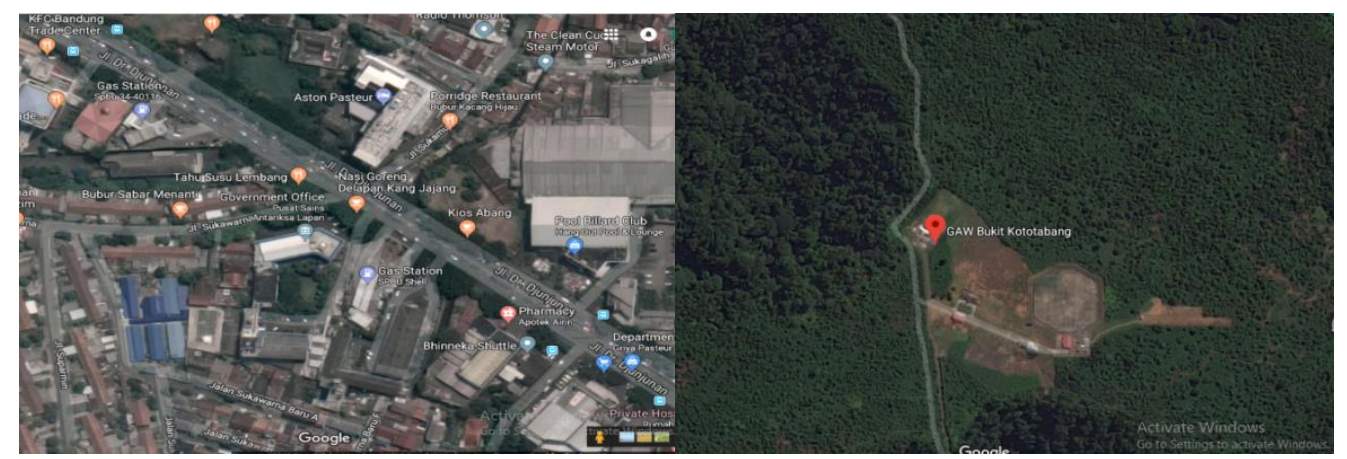

Gambar 1Lokasi Lapan Bandung dan Stasiun GAW Bukit kototabangdi ambil dari google map 2018

\section{METODOLOGI PENELITIAN}

Keberadaan alat ukur gas $\mathrm{CO}$ dan $\mathrm{O}_{3}$ yang di wilayah Sumatera Barat sampai dengan saat penulisan karya ilmiah ini hanya ada di Stasiun GAW Bukit Kototabang. Hal ini karena Staiun GAW Bukit Kototabang merupakan Stasiun Referensi Udara Bersih Global untuk wilayah Indonesia. Terkait dengan ide dan ketersediaan data maka dipilih Lapan
Bandung sebagai sample dari kondisi di wilayah perkotaan dan Stasiun GAW Bukit Kototabang sebagai sample wilayah non perkotaan.

Penggunaan alat ukur gas baik di Stasiun GAW Bukit Kototabang maupun di Lapan Bandung selalu menjaga kualitas data. Adanya koreksi dan telah terkalibrasi secara standar dari badan/lembaga yang berkompeten adalah salah satu kegiatanrutin untuk menjamin output data yang dihasilkan.Karena faktor 
data tersebut, maka data tahun 2008 akan digunakan sebagai sampleuntuk mendapatkan gambaran profil diurnal gas CO dan pembentukan O3.Banyak sekali aspek yang mempengaruhi pengukuran untuk mendapatkan data sesuai dengan kondisi sebenarnya sehingga hal ini menjadi keterbatasan dalam ketersediaan data.

Jenis data gas $\mathrm{CO}$ dan $\mathrm{O}_{3}$ yang digunakan untuk analisis berupa data primer hasil pengukuran di Stasiun GAW Bukit Kototabang sedangkan data gas CO dan $\mathrm{O}_{3}$ untuk wilayah Bandung digunakan data sekunder karena data tersebut diambil dari kajian ilmiah oleh Novita Ambarsari et al (2010)yangmanapengukuran gas $\mathrm{CO}$ dan $\mathrm{O}_{3}$ dilakukan di Lapan Bandung.

Pengukuran diurnal konsentrasi gas $\mathrm{CO}$ di stasiun GAW Bukit Kototabang dilakukan dengan Horiba Ambient Carbon Monoxide Monitor type APMA360dan di lapan Bandung menggunakan Horiba Ambient Carbon Monoxide Monitor tipe APMA370. Secara konsep dasar kerja dan prinsip pengukuran gas CO dengan Horiba Ambient Carbon Monoxide Monitor type APMA-360danHoriba Ambient Carbon Monoxide Monitor tipe APMA370adalah sama dan sejenis, perbedaan hanya terdapat pada seri keluaran model. Untuk menjaga konsistensi dan kualitas data maka secara berkala diadakan kalibrasi terhadap alat tersebut.

Untuk pengukuran gas $\mathrm{O}_{3}$ di stasiun GAW Bukit Kototabangdilakukan dengan menggunakan TEI 49C Surface OzonAnalyze. dandi Lapan bandung $\mathrm{O}_{3}$ diukur dengan menggunakan instrumen Monitor Ozon 1006$A H J$. Prinsip dasar kerja kedua alat tersebut sama. Masing-masing alat mempunyai faktor koreksi dan terkalibrasi secara standar sehingga datayang dihasilkan dapat dipertanggungjawabkan dan mencerminkan kondisi yang sebenarnya.

Grafik diurnal $\mathrm{O}_{3}$ dan gas $\mathrm{CO}$ dari Stasiun GAW Bukit Kototabang dan Lapan Bandung akan dianalisis profil dan model pembentukan $\mathrm{O}_{3}$. Konsentrasi harian gas $\mathrm{CO}$ dan $\mathrm{O}_{3}$ akan dibuat rata-rata tiap bulan sehingga menghasilkan grafik keadaan konsentasi tiap bulan pada tahun 2008. Sebagai contoh grafik profil dan model keadaan konsentrasi gas CO dan 03 akan dipilih beberapa bulan yang dengan mempertimbangkan kualitas data dan kelengkapan dari ketersediaan data itu sendiri.

\section{HASIL DAN PEMBAHASAN}

\section{Profil diurnal Gas CO}

Pada Gambar 2 yaitu profil diurnal gas CO selama tahun 2008 Lapan Bandung menerangkan bahwa konsentrasi gas $\mathrm{CO}$ terdapat 2 puncak (jam 07.00 dan 17.00 Wib) dan 1 lembah (jam 13.00 WIB). Sedangkan pada gambar 3 berupa profil diurnal gas CO selama tahun 2008 stasiun GAW Bukit Kototabang diketahui bahwa secara diurnal konsentrasi gas CO relatif stabil. Perbedaan type wilayah (perkotaan dan non-perkotaan) menjadikan perbedaan jumlah gas CO yang dihasilkan. Perbedaan ini menjadikan perbedaan terhadap profil diurnal gas CO antara Lapan Bandung dan GAW Bukit Kototabang.

Kenaikan konsentrasi gas CO yang cepat di Lapan Bandung pada pagi dan sore hari berhubunganan dengan aktifitas wargaperkotaan yang tinggi pada waktu tersebut. Penurunan konsentrasi gas CO di Lapan Bandung dan GAW Bukit kototabang terjadi mulai sekitar jam 09.00 WIB. Konsentrasi minimum gas $\mathrm{CO}$ terjadi sekitar jam 13.00 WIB hingga jam 15.00 WIB.Peningkatan konsentrasi gas $\mathrm{CO}$ di Lapan Bandung terjadi lagi ketika hari mulai sore.

Aktifitas warga non perkotaan yang rendah sebagai penghasil gas CO menjadikan profil konsentarsi gas CO yang terukur di stasiun GAW Bukit Kototabang relatif stabil.Secara diurnal tidak ada perbedaan yang besar terhadap konsentrasi gas CO yang terukur di stasiun GAW Bukit Kototabang.

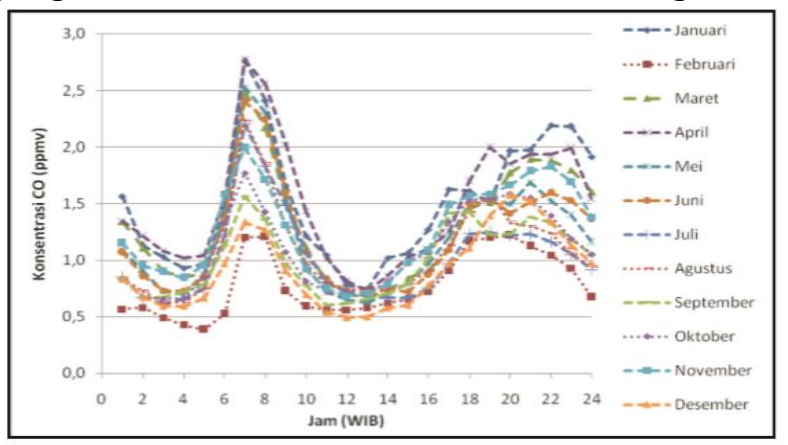

Gambar 2 Variasi Diurnal CO Bulanan selama Tahun 2008 Lapan Bandung

Sumber : Novita Ambarsari dkk, 2010

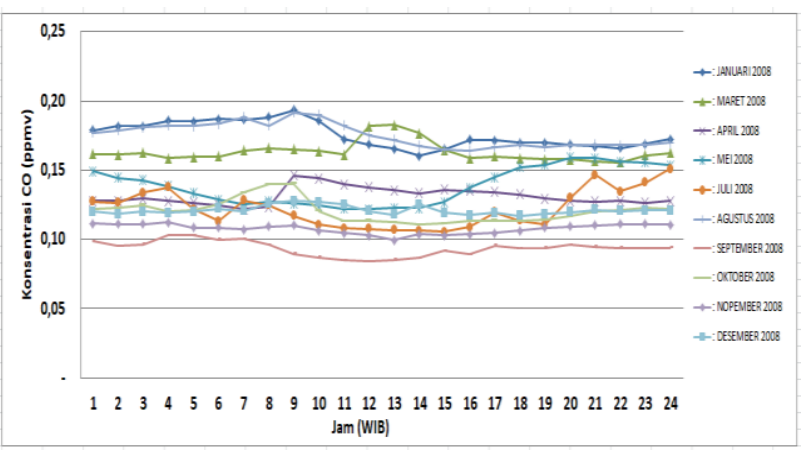

Gambar 3 Variasi Diurnal CO Bulanan selama Tahun 2008 GAW Bukit Kototabang

\section{Profil Diurnal $\mathrm{O}_{3}$}

Pada malam dini hari hingga matahari mulai bersinar, konsentrasi gas $\mathrm{O}_{3}$ baik di Lapan Bandung ataupun GAW Bukit Kototabang secara umum terukur konsentrasi gas $\mathrm{O}_{3}$ yang relatif kecil (gambar 4 dan 5). Peningkatan konsentrasi $\mathrm{O}_{3}$ di Lapan bandung dan Gaw Bukit Kototabang secara umum terjadi sekitar jam 08.00 WIB hingga sekitar jam 17.00 WIB. Pola profil secara diurnal untuk $\mathrm{O}_{3}$ antara Lapan Bandung dan GAW Bukit Kototabang secara umum sama yaitu terjadinya puncak pada saat maximum penyinaran matahari. Nilai maximum konsentrasi $\mathrm{O}_{3}$ terukur di Lapan Badung terjadi pada sekitar jam 11.00 WIB s/d jam 14.00 WIB sedangkan untuk GAW Bukit Kototabang nilai maximum terukur terjadi antara jam 
12.00 WIB s/d 17.00 WIB. Peningkatan dan penurunan konsentrasi $\mathrm{O}_{3}$ berkaitan dengan adanya proses fotokimia yang energinya berasal dari sinar matahari.

Jika dibandingkan secara kuantitatif, konsentrasi $\mathrm{O}_{3}$ di Lapan Bandung masih jauh lebih tinggi dari yang terukur di GAW Bukit Kototabang. Hal ini tidak lepas dari berbedaan type wilayah antara Lapan Bandung dan GAW Bukit Kototabang sebagai sumber emisi pembentukan $\mathrm{O}_{3}$. Pada gambar $1 \mathrm{di}$ atas diketahui bahwa Lapan Bandung berada di perkotaan sehingga aktifitas warga yang tinggi sehingga potensi konsentrasi gas CO tinggi sedangkan wilayah stasiun GAW Bukit Kototabang berupa non perkotaan dengan aktifitas warga yang rendahmenjadikan potensi konsentrasi gas $\mathrm{CO}$ rendah.

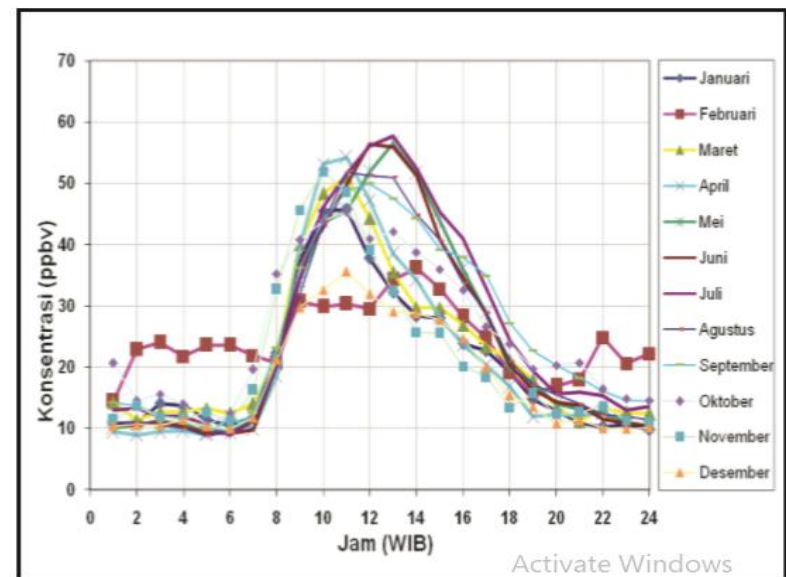

Gambar 4 Variasi Diurnal 03 Bulanan Tahun 2008 Lapan Bandung

Sumber : Novita Ambarsari dkk, 2010

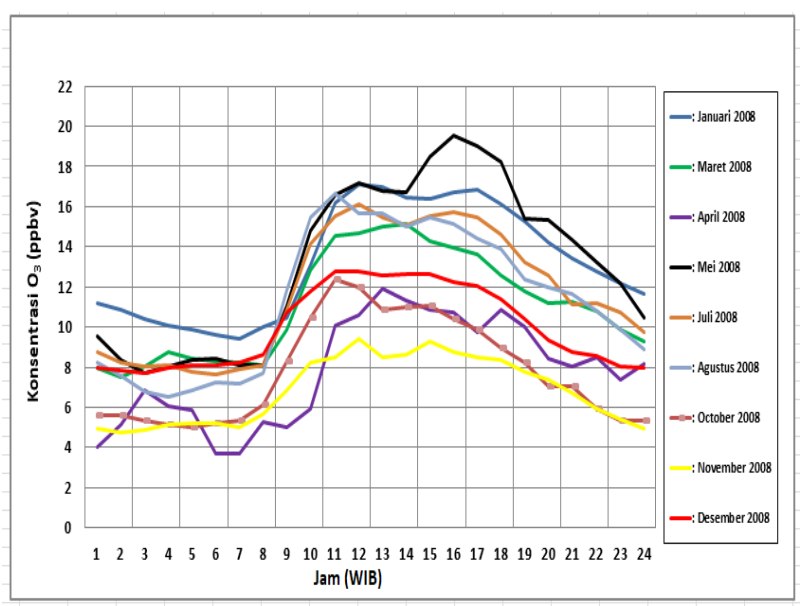

Gambar 5 Variasi Diurnal 03 Bulanan Tahun 2008 GAW Bukit Kototabang

\section{Profil Diurnal Pembentukan 03 oleh Gas Co}

Grafik rata-rata harian 03 dan gas CO bulan Januari 2008 dan Agustus 2008 dari Stasiun GAW Bukit Kototabang dan Lapan Bandung akan disajikan sebagai sampleprofil dan model pembentukan 03 oleh gas CO.

Pada gambar 6 terlihat bahwa konsentrasi gas CO di Bandung mengalami peningkatan pada mulai jam 06.00 WIB hingga sekitar jam 07.00 WIB dan sore hari jam 17.00 WIB. Proses fotokimia pembentukan $\mathrm{O}_{3}$ sejalan dengan penurunan konsentrasi gas $\mathrm{CO}$ yang mana ini terjadi pada interval waktu jam 11.00-13.00 WIB. Menurut Novita Ambarsari et all (2010), gas CO kemudian digunakan untuk menghasilkan ozon permukaan sesuai reaksi 2 dengan selang waktu hingga siang hari (pukul 11.00-13.00).

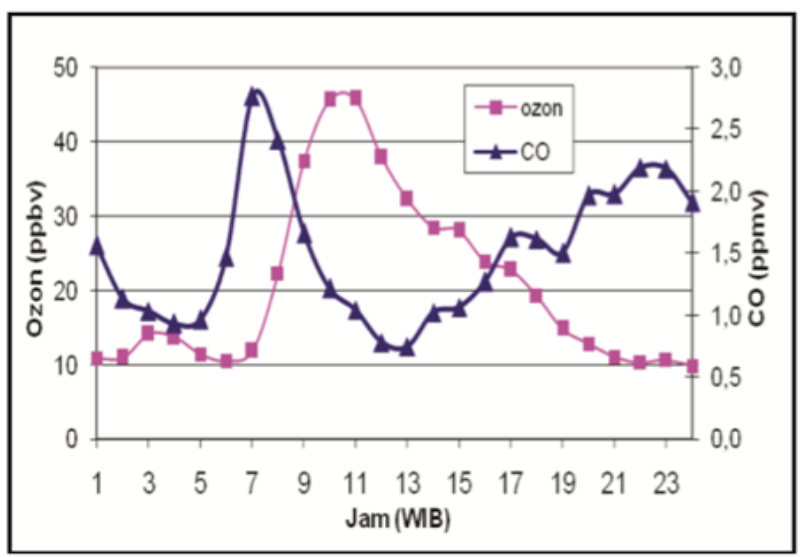

Januari

(a)

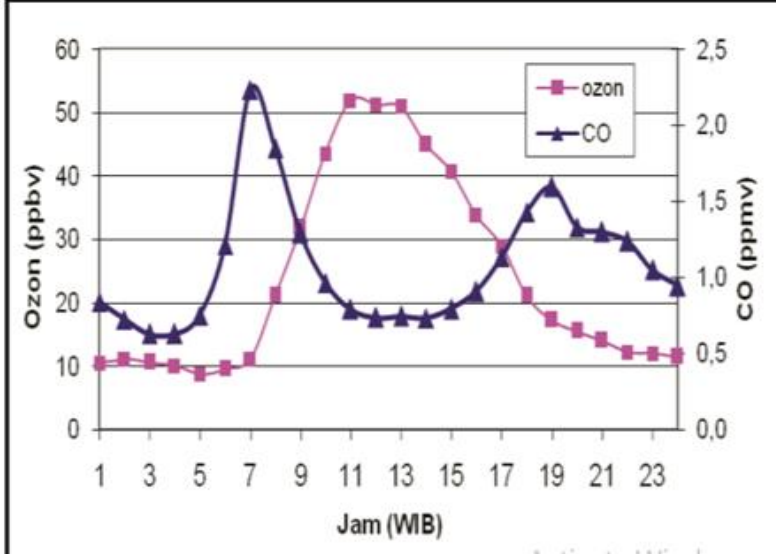

(b)

Agustus

Gambar6 (a) dan (b).

Variasi Diurnal $0_{3}$ dan CO Bulan Januari dan Agustus Tahun 2008 Lapan Bandung

Sumber : Novita Ambarsari dkk, 2010

Aktifitas warga kota Bandung pada sore hari menjadikan peningkatan konsentrasi gas CO. Sinar matahari yang melemah menjadikan proses fotokimia untuk merombak $\mathrm{O}_{2}$ menjadi prekursor $\mathrm{O}_{3}$ rendah sehingga pembentukan $\mathrm{O}_{3}$ pada saat sore dan malam hari rendah. Selain rendahnya proses fotokimia perombakan gas $\mathrm{O}_{2}$ pada sore dan malam hari, hasil respirasi tanaman pada malam hari diprakirakan ikut andil dalam peningkatan konsentrasi gas $\mathrm{CO}$ malam hari.

Pada gambar 7 yaitu grafik variasi diurnal gas $\mathrm{CO}$ dan $\mathrm{O}_{3} \mathrm{GAW}$ Bukit Kototabang. Dari grafik gambar ini tidak memperlihatkan peningkatan konsentrasi yang tinggi seperti halnya yang ada di grafik gambar 6. Sebaran rata-rata nilai tiap jam konsentarsi Gas COdi stasiun GAW Bukit Kototabang memilikinilai yang stabi, hal ini karena aktifitas warga yang rendah 
di wilayah sekitar Stasiun GAW Bukit Kototabang sehingga tidak terjadipeningkatan konsentrasi gas CO secara besar saat itu.

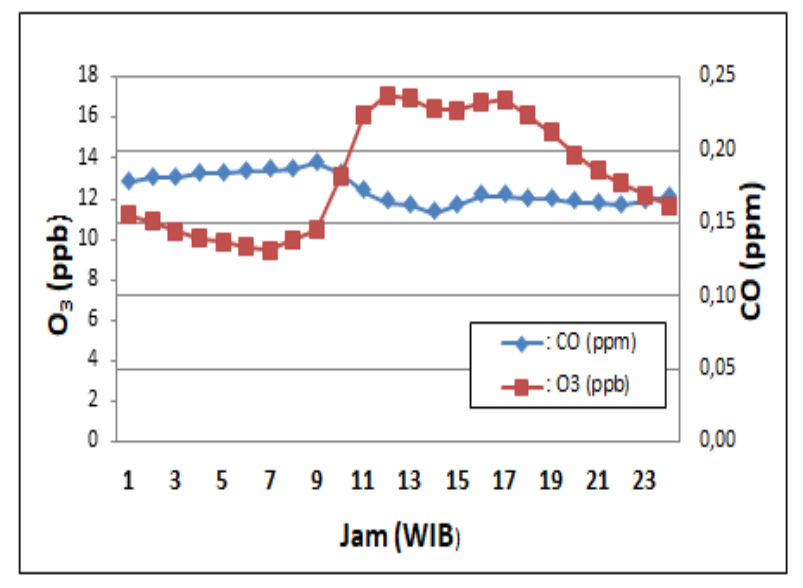

Januari

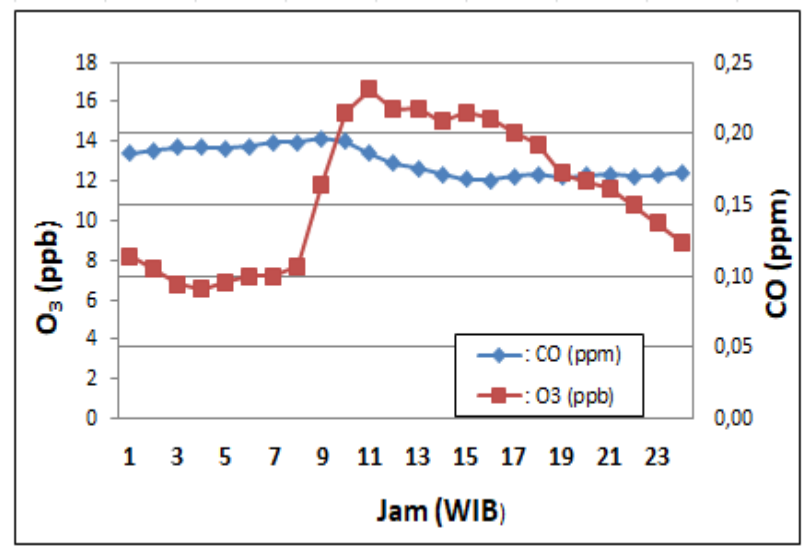

Agustus

Gambar 7Variasi Diurnal $\mathrm{O}_{3}$ dan CO Bulan Januari dan Agustus Tahun 2008 GAW Bukit Kototabang

Peningkatan diurnal konsentrasi $\mathrm{O}_{3}$ terjadi sekitar jam 09.00 WIB hingga sekitar jam 17.00 WIB berkesesuaian dengan proses fotokimia pembentukan O3yangmana energi pengaktifan proses berasal radiasi matahari. Penurunan konsentrasi sejalan dengan intensitas radiasi matahari yang mulai rendah. Periode saat penurunan konsentrasi gas CO sejalan dengan waktu peningkatan pembentukan $\mathrm{O}_{3}$. Kejadian oleh proses fotokimia ini terjadi pada siang hingga sore hari. Setelah intensitas matahari mulai lemah maka sekitar jam 17.00 WIB konsentrasi dari $\mathrm{O}_{3}$ mengalami penurunan sedangkan konsentrasi CO yang terukur di Stasiun GAW Bukit kototabang saat itu pada keadaan yang konstan.

Adanya perbedaan tipe wilayah dan sumber polutan antara Stasiun GAW Bukit Kototabang dan Lapan Bandung menyebabkan perbedaan jumlah konsentrasi $\mathrm{CO}$ dan gas $\mathrm{O}_{3}$ yang dihasilkan dari proses fotokimia. Profil pembentukan $\mathrm{O}_{3}$ di Stasiun GAW Bukit Kototabang dan Lapan Bandung secara umum adalah sama yaitu sejalan dengan mulainya aktifitas penyinaran matahari untuk merombak gas $\mathrm{CO}$ dan $\mathrm{O}_{2}$ yang selanjutnya akan digunakan untuk pembentukan $\mathrm{O}_{3}$ sesuai dengan alur reaksi kimia kedua.

\section{KESIMPULAN}

Peningkatan konsentrasi ozon permukaan $\left(\mathrm{O}_{3}\right)$ seiring dengan penurunan konsentrasi gas $\mathrm{CO}$ berkaitan dengan reaksi fotokimia oksidasi CO. Profil diurnal ozon permukaan yang terbentuk di Lapan Badung dan stasiun GAW Bukit Kototabang berkesesuaian yaitu penurunan variasi diurnal gas CO pada siang hari dan terjadi peningkatan konsentrasi ozon permukaan pada siang hari.

Perbedaan profil konsentrasi yang jelas antara Lapan Bandung dan Stasiun GAW Bukit Kototabang terhadapwaktu emisi gas CO. Pada wilayah tipe perkotaan, peningkatan diurnal konsentrasi gas $\mathrm{CO}$ jelas terlihat sejalan dengan aktifitas warga perkotaan sedangkan pada daerahnon-perkotaan profil diurnal kenaikan gas CO tidak begitu jelas terlihat.

Perbedaan kecuraman penurunan nilai kosentrasi CO baik di Lapan Bandung maupun stasiun GAW Bukit Kototabang pada siang hari terkait untuk proses pembentukan $\mathrm{O}_{3}$. Lembah konsentrasi rendah pada siang hari di Lapan Bandung jelas terlihat jika dibandingkan dengan lembah konsentrasi CO siang hari di stasiun GAW Bukit Kototabang.

Dengan berdasar baku mutu udara ambien PP No. 41 Tahun 1999, jumlah konsentrasi $\mathrm{O}_{3}$ dan gas $\mathrm{CO}$ pada tahun 2008 untuk Kota Bandung (Lapan Bandung) dan stasiun GAW Bukit Kototabang masih berada pada kondisi baik. Usaha untuk mengurangi emisi polutan gas $\mathrm{CO}$ yang ada di perkotaan maupun non perkotaan harus terus dilakukan karena peningkatan emisi gas CO akan meningkatkan parameter polutan lainnya.

\section{DAFTAR PUSTAKA}

Ambarsari, Novita. 2015. Efek Radikal Hidroxyl (OH) dan Nitric Oxide (NO) dalam Reaksi Kimia Ozon di Atmosfer.Berita Dirgantara, 16 (2): 47-53.

Ambarsari, Novita., Komala, Ninong., dan Budiyono, Afif . (2010). Pengaruh Karbon Monoksida terhadap Ozon Permukaan.

(http://widyariset.pusbindiklat.lipi.go.id/index.php/w idyariset, diakses 6 Juni 2018)

Bloomer, Bryan J., Stehr, Jeffrey W., Piety, Charles A., Salawitch, Ross J., dan Dickerson, Russell R. 2009. Observed Relationships of Ozone Pollution with Temperature and Emissions. Geophysical Research Letters, 36 (9): 1-5.

Jin, Xiaomeng., dan Holloway, Tracey. 2015. Spatial and Temporal Variability of Ozone Sensitivity Over China Observed from the Ozone Monitoring instrument. Journal of Geophysical Research Atmospheres, 120(14) :7229-7246.

Lelieveld, Jos., dan Dentener, Frank J. 2000.What controls tropospheric ozone?. Journal of Geophysical Research Atmospheres, 105(D3):3531-3551.

Monks, Paul S. 2000. A review of the observations and origins of the spring ozonmaximum.Atmospheric Environment, 34: 3545-3561.

Peraturan Pemerintah No.41 Tahun 1999 tentang Baku Mutu Udara Ambien 
Sanjaya, Wisnu Karya. 2001. Analisis Hubungan SunShine dan Ozon Permukaan Di Jakarta. STMKG jakarta

Spivakovsky, C. M., Logan, J. A., Montzka, S. A., Balkanski, Y. J., Foreman-Fowler., et al .2000. Three-dimensional climatological distribution of tropospheric $\mathrm{OH}$ : Update and evaluation. Journal of Geophysical Research Atmospheres,105 (D7):8931-8980.
Susmiati,

Rahmi.2013.Pengertian

Fotokimia. https://rahmisusmiati.wordpress.com/2013/04/04/p engertian-fotokimia/. Diakses 25 Juni 2018.

Zhang, Lin., Jacob, Daniel J., Bowman, Kevin W., Logan, Jennifer A., Turquety, Solene., at al. 2006. Ozone-CO correlations determined by the TES satellite instrument in continental outflow regions.Geophysical Research Letters, 33: 1-5. 